\title{
The taxonomic significance of the short-shafted mesotriaene reviewed by parsimony analysis: validation of Pachastrella ovisternata Von Lendenfeld (Demospongiae: Astrophorida)
}

\author{
Manuel Maldonado \\ Centre d'Estudis Avançats de Blanes, Cami de Santa Bàrbara s/n, 17300-Blanes, Girona, Spain
}

Keywords: Astrophorida, Pachastrellidae, parsimony analysis, sponges, taxonomy

\begin{abstract}
The spicule complement of a demosponge specimen collected from the Atlantic coast of Spain was noted to be similar to that of Pachastrella monilifera, but particularly characterized by the presence of short-shafted mesotriaenes. After detailed examination, it was concluded that the specimen undoubtedly belonged to the species Pachastrella ovisternata Von Lendenfeld, 1894. For a long time, this species has been regarded a synonym of Pachastrella monilifera Schmidt, 1868. Examination of this new specimen showed that Pachastrella ovisternata was a valid species of the genus Pachastrella. Moreover, it denoted the real existence of mesotriaenes in this genus.

The parsimony analyses indicated that the species Yodomia perfecta, traditionally assigned to the genus Yodomia by the presence of mesotriaenes, ought to be reclassified in the genus Pachastrella, close to $P$. ovisternata. These analyses also showed that mesotriaenes are a product of a convergent evolution in shape of tetraxon spicules in Calthropellidae and Pachastrellidae. At the species level it is suggested that short-shafted mesotriaenes have arisen more than once in the family Pachastrellidae. Thus, the presence of mesotriaenes itself cannot be regarded as a diagnostic characteristic at generic level. However, it was noted to be a reliable feature in order to distinguish taxa at specific level.
\end{abstract}

\section{Resumen}

La espiculación de un ejemplar de demosponja procedente de las costas atlánticas españolas se apreció muy similar a la de Pachastrella monilifera, pero caracterizada por la presencia de mesotrienas de rabdoma corto. Tras un estudio detallado se ha concluido que dicho ejemplar pertenece a la especie Pachastrella ovisternata Von Lendenfeld, 1894. Esta especie, sin embargo, ha sido considerada, desde hace mucho tiempo, un sinónimo de Pachastrella monilifera Schmidt, 1868. La descripción de este nuevo ejemplar prueba que $P$. ovisternata es una especie válida y corrobora la existencia de mesotrienas de rabdoma corto en especies del género Pachastrella.

Los análisis de parsimonia muestran que la especie Yodomia perfecta, tradicionalmente asignada al género Yodomia por la presencia de mesotrienas, debería ser reclasificada en el género Pachastrella, cerca de $\boldsymbol{P}$. ovisternata. Los análisis indican también que las mesotrienas que aparecen en Calthropellidae y Pachastrellidae son el resultado de una evolución convergente en la forma de las espículas tetraxonas de estos dos grupos. El estudio a nivel específico indica que las mesotrienas han surgido más de una vez en el seno de la familia Pachastrellidae. Por tanto, la presencia de mesotrienas no puede ser considerada, en sí misma, como un carácter diagnóstico a nivel de género. Sin embargo, se ha mostrado como un carácter muy fiable para distinguir taxones a nivel específico.

\section{Introduction}

Demosponges with short-shafted mesotriaenes (mesocalthrops or mesodichotriaenes) are extremely rare. According to the literature, these spicules are present in species belonging to the family Calthropellidae, such as Pachastrissa pathologica (Schmidt, 1868) (sensu Von Lendenfeld, 1903; Lévi, 1973) and Pachataxa enigmatica Lévi \& Lévi, 1983. They also occur in some pachastrellids, such as the species of the genera Yodomia Lebwohl, 1914 (sensu Dendy, 1916) and Triptolemus Sollas, 1888. Additionally, a peculiar case of short-shafted mesotriaenes becoming desmas has been reported by Lévi \& Lévi (1989) in the enigmatic genus Brachiaster Wilson, 1925.

Many of these descriptions of species with 
mesotriaenes are very ancient. Furthermore, most species have not been recorded since their initial description, except in a few cases. In such cases, the short lists of records indicate that these species are usually limited to a small geographical area. Consequently, most of these species are presently regarded as taxonomic oddities. The genus Yodomia, for instance, has virtually been forgotten by presentday taxonomists, although it was never invalidated. Consequently, the existence of diverse types of mesotriaenes has unfortunately gone unnoticed in interesting discussions on the evolution and relationships of the tetraxon spicules (e.g., Reid, 1970; Lévi, 1991). The taxonomic history of the genus Brachiaster, which was recently reclassified from Lithistida "incertae sedis" (Wilson, 1925) to Astrophorida, Pachastrellidae (Lévi \& Lévi, 1989) and subsequently relocated in Lithistida Tetracladina (Lévi, 1991), is also indicative of the systematic instability affecting most of the species concerned in this study.

The collection of a new pachastrellid specimen with mesotriaenes prompted the present investigation on the relationships between taxa that have short-shafted mesotriaenes, using parsimony analysis.

\section{Materials and methods}

The specimen described here was collected during an expedition carried out in 1982 by the Spanish Institute of Oceanography. The location data were: muddy bottom at $300 \mathrm{~m}$ deep, near Cape Finisterre (northeastern Atlantic coast of Spain); latitude/longitude are unknown. The specimen was preserved dry and deposited in the Museo Nacional de Ciencias Nacionales in Madrid (MNCN-01.01/6). The holotype of Pachastrella ovisternata, borrowed from the Naturhistorisches Museum Wien (NMWInv.Nr. 525 and 526) was checked against the collected specimen and material described by Ferrer-Hernández (1914) under the name of Pachastrella ovisternata (MNCN-202 \& 203, according to the old code).

Type material and abundant other material stored in the British Museum of Natural History in London (BMNH), the Museo Civico di Storia Naturale "G. Doria" in Genoa (MSNG) and MNCN were examined in order to adequately record characteristics at generic level. Type material examined was as follows: Characella pachastrelloides (Carter, 1876) (BMNH: IO:I:1680 and 1681), Characella tripodaria (Schmidt, 1868) (BMNH: 68:3:2:36), Poecillastra rudiastra Pulitzer-Finali, 1983 (MSNG: C:E:47161), Sphinctrella linaresi Ferrer-Hernández, 1914
(MNCN: 36, according to the old code), Sphinctrella gracilis Sollas, 1888 (BMNH: 94:11:16:144 to 146), Sphinctrella horrida Schmidt, 1870 (BMNH: 70:5:3:47), Sphinctrella cribrifera Sollas, 1888 (BMNH: 89:1:1:39), and Calthropella simplex Sollas, 1888 (BMNH: ?, schizotype stored as substratum of $S$. cribrifera). In addition, some specimens collected in the Alboran Sea belonging to the species cited below, were also examined: Pachastrella monilifera Schmidt, 1868, Poecillastra compressa (Bowerbank, 1866), Poecillastra amygdaloides (Carter, 1876), Spinctrella verrucolosa Pulitzer-Finali, 1983, Stoeba plicatus (Schmidt, 1868), Dercitus bucklandi (Bowerbank, 1861) and Pachastrissa pathologica (Schmidt, 1868). Other data required were obtained from descriptions in scientific literature.

The skeletal study was accomplished using the standard methodology (Rützler, 1978). Micrographs were obtained using a HITACHI-S-2300 SEM.

The parsimony analyses were performed using "Paup $3.0 \mathrm{~g}$ " (Swofford, 1989), according to the assumptions explained in the text.

\section{Systematic description}

Genus Pachastrella Schmidt, 1868

Pachastrella ovisternata Von Lendenfeld, 1894

(Fig. 1; Pls. I-III)

Synonymy. - Pachastrella ovisternata Von Lendenfeld, 1894: 439.

Pachastrella monilifera (Schmidt); Topsent, 1902: 14; 1904: 93, 94 (in part).

Non: Pachastrella ovisternata sensu Ferrer-Hernández, 1914: 7 (=P. monilifera).

Description. - Massive specimen, irregular in shape and $20 \times 20 \times 14 \mathrm{~cm}$ in size (P1. I). The surface is uneven, wrinkled in some areas and usually covered with slime. Ostia are circumscribed to a large concave area resulting from a convoluted fold. Non-aquiferous conical papillae, $5-8 \mathrm{~mm}$ in height, along with hispidating tracts, protruding 3-4 $\mathrm{mm}$, present on the inhalant surface. Oscules are $1-2 \mathrm{~mm}$ in diameter, scattered on the remaining surface. Colour greyish white. Stony consistency when dry.

Spicules:

Oxeas: curved or slightly flexuous, blunt-pointed (Figs. 1a, b), 3600-7500 $\mu \mathrm{m} \times 16-45 \mu \mathrm{m}$ in size. Calthrops and pseudocalthrops: clads are usually 


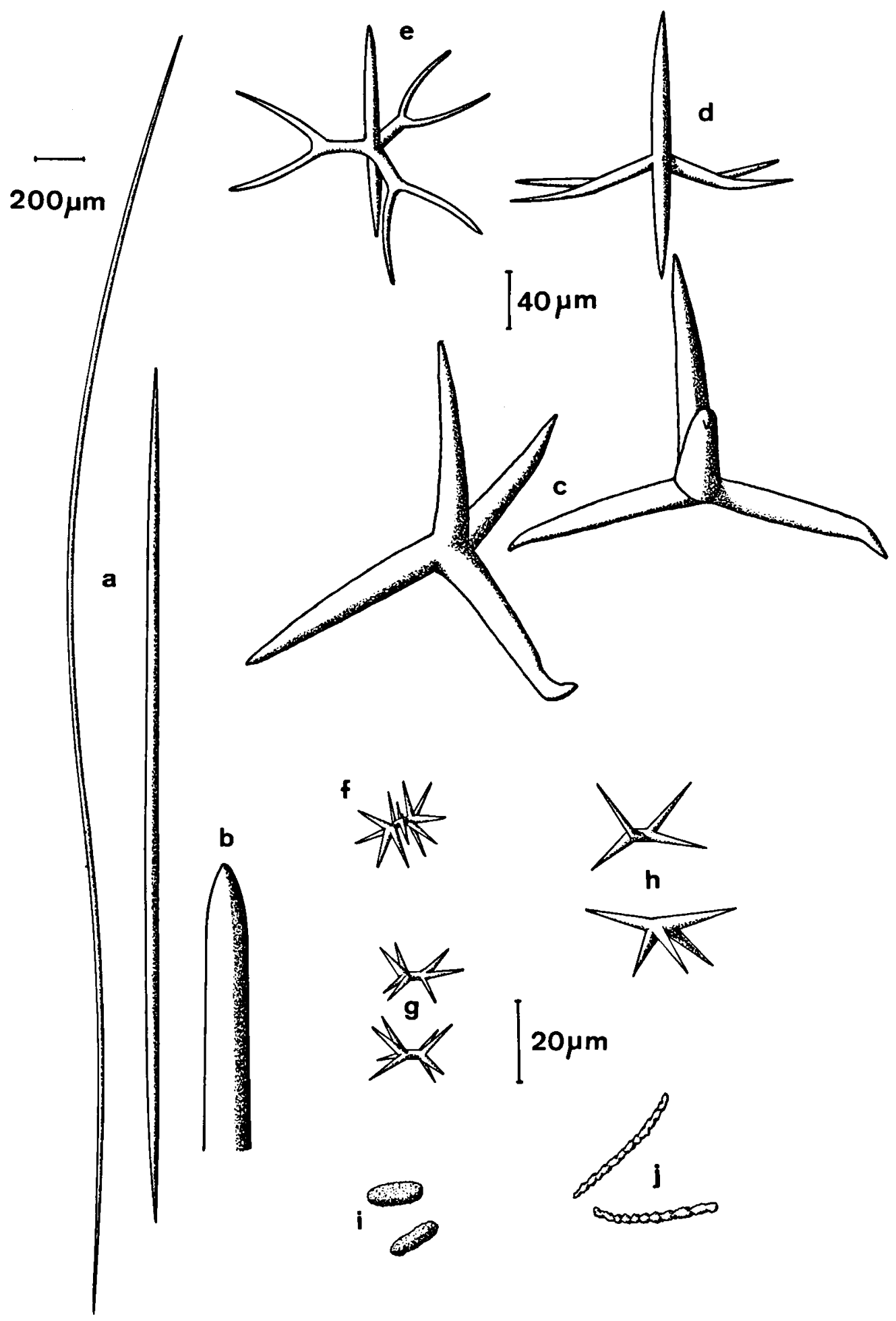

Fig. 1. Spicules of Pachastrella ovisternata: (a) oxeas, (b) blunt end of oxea, (c) calthrops, (d) dichotriaene, (e) mesotriaene, (f) metaster, (g) amphiasters, (h) plesiasters, (i) oval microstrongyles, (j) microrhabdoid streptaster. 


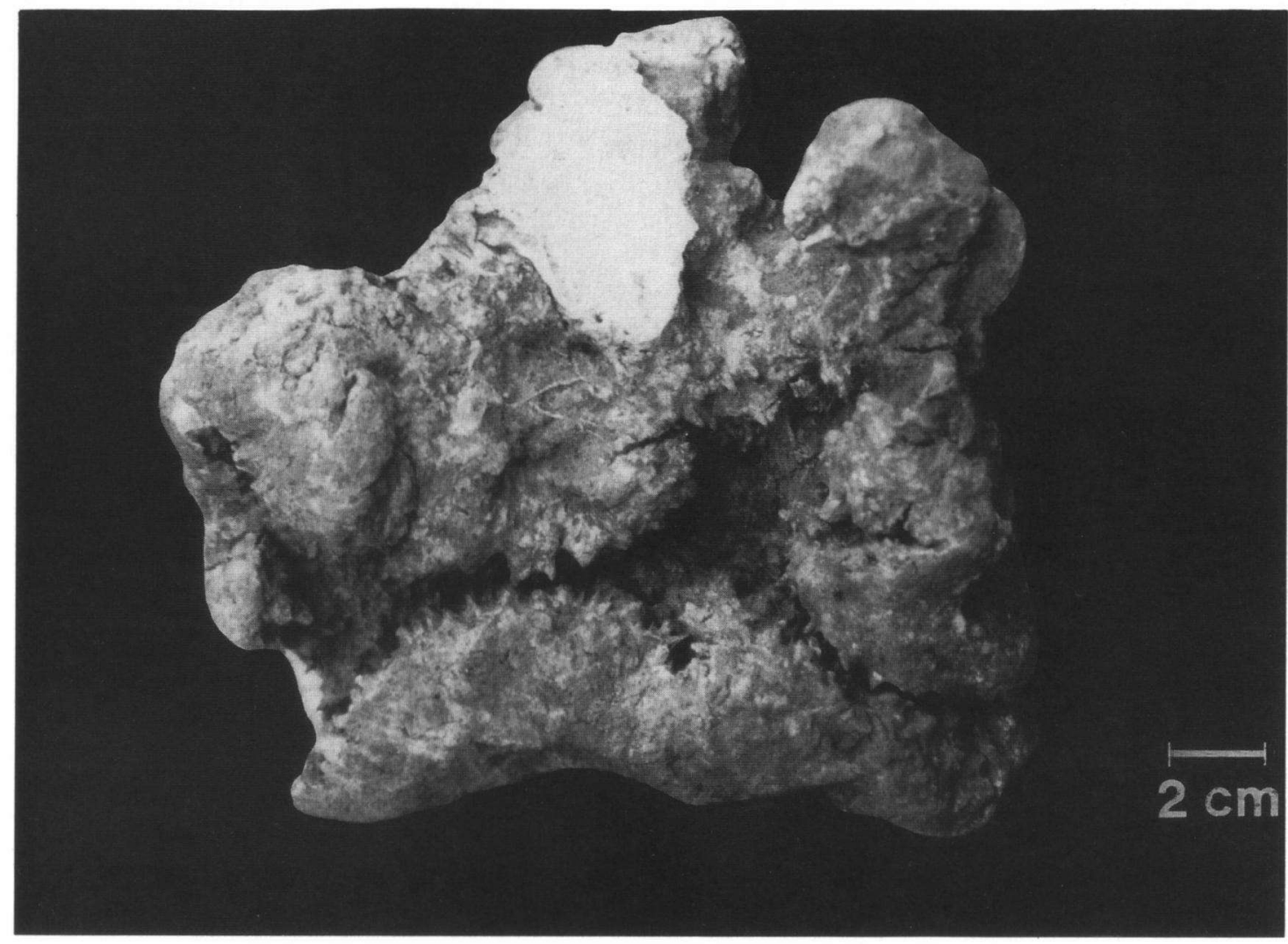

Plate I. Overall view of the specimen.

straight in the smaller forms, but malformations are occasionally observed in the greater forms (Fig. 1c, Pl. Ilb). Clads display a wide range in size, measuring 122-1100 $\mu \mathrm{m} \times 8-55 \mu \mathrm{m}$.

Dichotriaenes: short-shafted, occasionally with one or two undivided clads only (Figs. 1d, e, Pl. IIa). The rhabdome measures $65-85 \mu \mathrm{m} \times 8-12 \mu \mathrm{m}$, the protoclads $25-40 \mu \mathrm{m} \times 8-12 \mu \mathrm{m}$, and the deuteroclads $46-95 \mu \mathrm{m} \times 7-10 \mu \mathrm{m}$. The rhabdome is usually shorter than the clads.

Mesodichotriaenes: similar to short-shafted dichotriaenes in which the shaft (rhabdome sensu lato) is prolonged on both sides of the cladome forming a rhabdome sensu stricto and an epirhabdome. Epirhabdome usually shorter than rhabdome sensu stricto (Fig. le; Pl. IIc, d). Clads are always dichotomous and no malformations were observed. Dimensions are similar to those of the dichotriaenes. Epirhabdome measures 40-85 $\mu \mathrm{m} \times$ 7-12 $\mu \mathrm{m}$.
Oval microstrongyles: usually elliptical in shape, fully covered with minute spines (Fig. 1i, Pl. IIId) and $12-19 \mu \mathrm{m} \times 5-9 \mu \mathrm{m}$ in size.

Microrhabdose streptasters: thin, very long forms (25-45 $\mu \mathrm{m} \times 1-2 \mu \mathrm{m}$ ), exhibiting strong spines or microspiny turbercles (Pl. IIIc; Fig. 1j). They are scarce. The thick central axis along with the groups of minute degenerate actines (resembling spines) made these spicules resemble polytylote microstrongyles when examined under the light microscope.

Similar spicules have been reported in some species of Triptolemus Sollas, 1888, Pachastrella, and Yodomia. They were initially described as microxeas or derived spicules (e.g., Carter, 1876; Sollas, 1888; Kirkpatrick, 1903), sometimes under the ambiguous name of "microrhabds" (e.g., Kirkpatrick, 1902; Pulitzer-Finali, 1971). However, I agree with authors such as Dendy (1916: 234), Sarà (1959) and Lévi \& Lévi (1983: 153), who have 

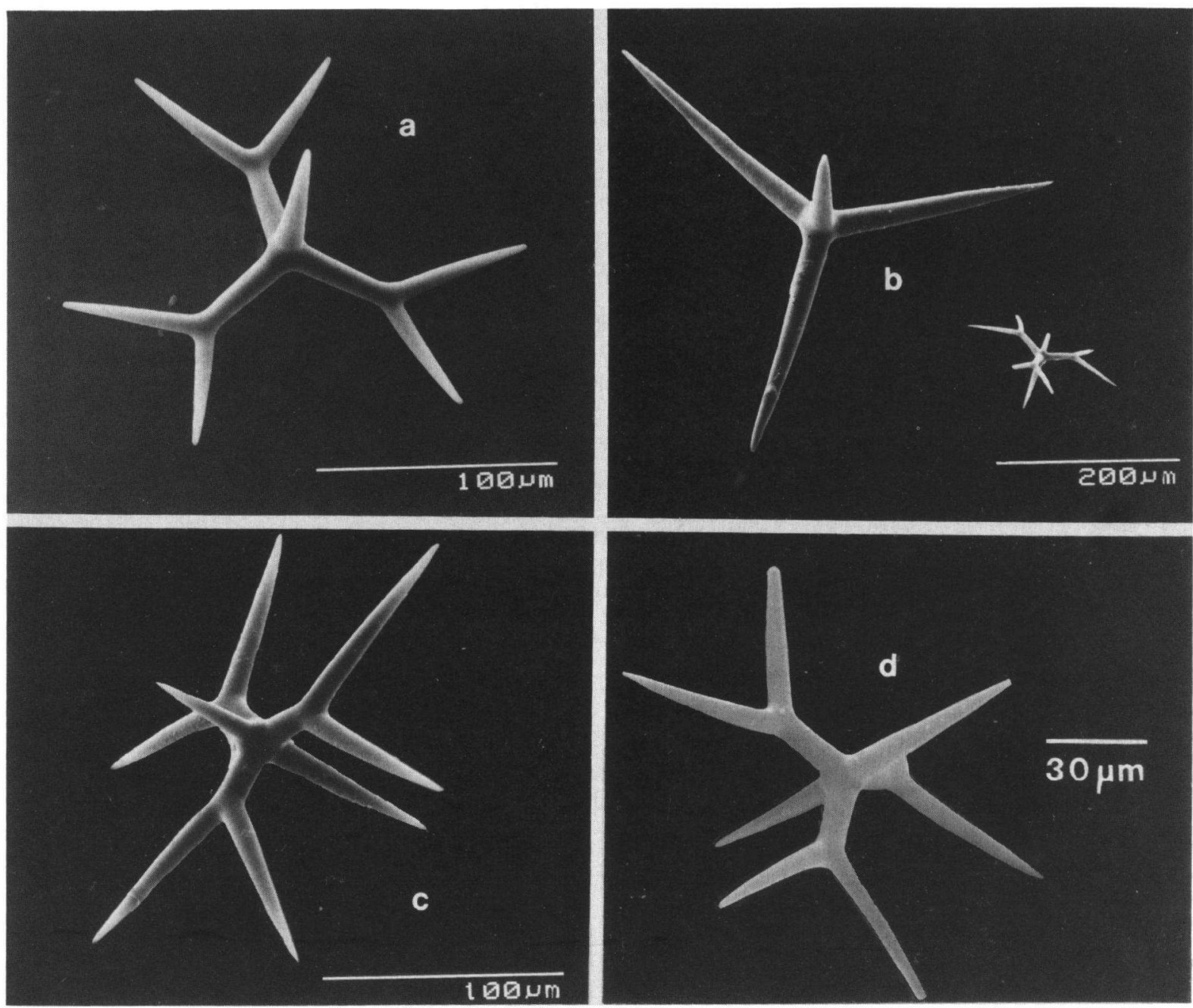

Plate II. Megascleres: (a) dichotriaene, (b) calthrops and dichomesotriaene, (c) \& (d) different views of dichomesotriaenes.

interpreted these spicules as reduced streptasters. Amphiasters: with short shaft and microspiny actines. Microspines are only evident under SEM examination (Fig. 1g, Pl. IIIa). The spicules are $17-22 \mu \mathrm{m}$ in their overall length, with actines measuring $6-10 \mu \mathrm{m}$ in length. They are very abundant. Amphiasters are very rarely transformed into sanidasters or metasters (Fig. 1f).

Plesiasters: with usually 3-5 actines covered by microspines (Fig. 1h; Pl. IIIb). Actines are 10-15 $\mu \mathrm{m}$ in length. They are very scarce.

\section{Skeleton:}

Spicules are densely arranged, providing a hard consistency to the sponge. A thick crust (1-1.5 $\mu \mathrm{m})$ of microstrongyles reinforces the ectosome. The choanosomal skeleton displays a diffuse architecture. Tracts of oxeas show a vague radial pattern from the inner choanosome up to the ectosome, protruding in long hispidating tufts at the inhalant zones. Calthrops are abundant everywhere in the choanosome, but no special spatial organization is apparent.

Dichotriaenes and mesodichotriaenes are more abundant in the inner choanosome, in contrast to the general pattern of the Astrophorida (Sollas, 1888). Streptasters are densely scattered everywhere in the choanosome. 

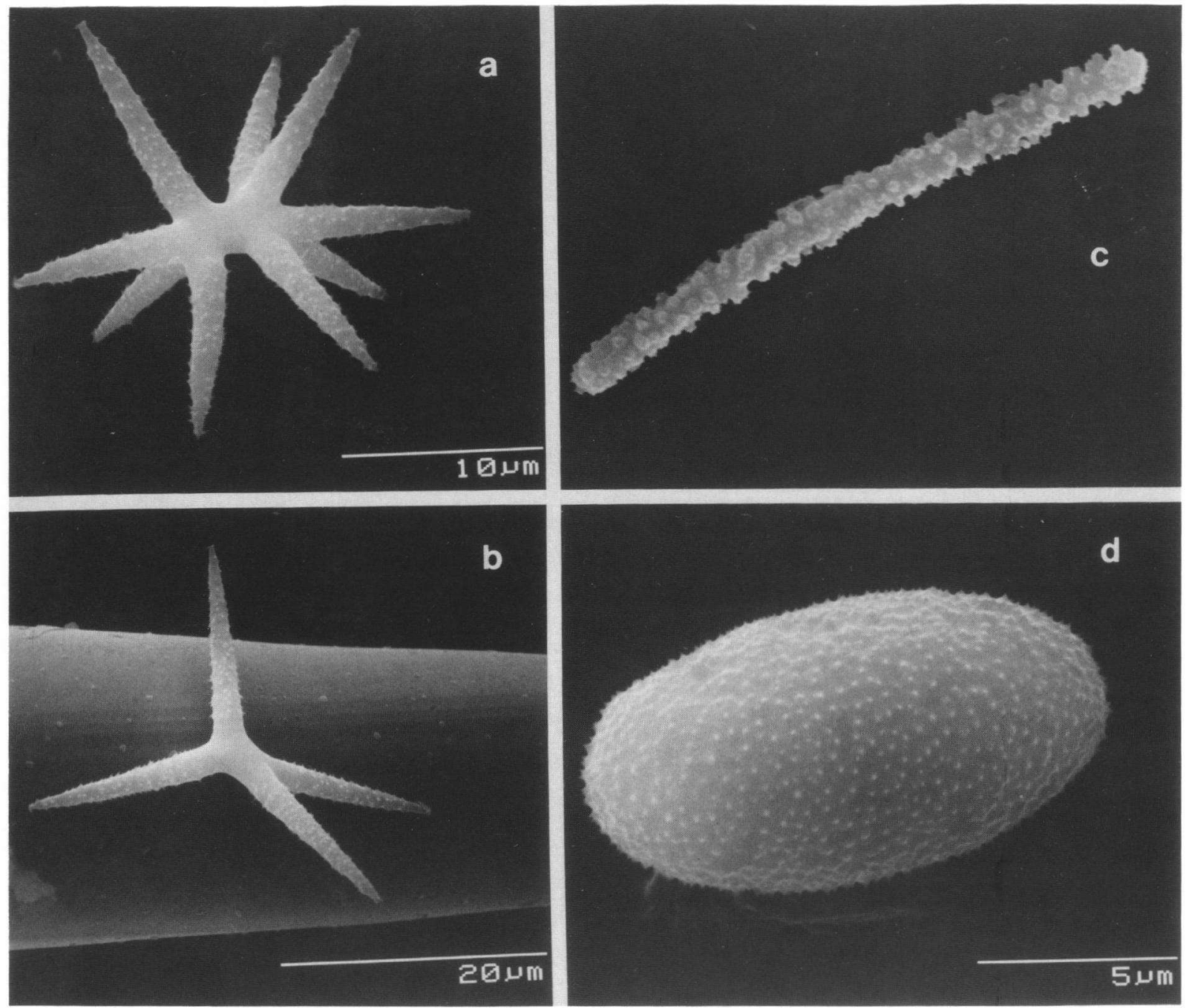

Plate III. Microscleres: (a) amphiaster, (b) plesiaster, (c) reduced streptaster, (d) oval microstrongyle.

Distribution. - Known only from the coasts of Portugal between Faro and Sines (Von Lendenfeld, 1894) and the coasts of Galicia (present record), at a depth of $300 \mathrm{~m}$. Specimens with mesodichotriaenes mentioned by Topsent (1902) under the name of Pachastrella abyssi might actually correspond to Pachastrella ovisternata, but data about their location were omitted by the author.

\section{Taxonomic discussion}

The collected specimen completely fits the holotype of Pachastrella ovisternata. Unfortunately, however, this interesting species has been disguised for a long time due to several consecutive systematic interpretations: (1) Von Lendenfeld (1903) explicitly defined the genus Pachastrella as Pachastrellidae without mesotriaenes (p. 73), although he paradoxically included in the same paper (p. 75) a description of $\boldsymbol{P}$. ovisternata, underlining the presence of characteristic mesodichotriaenes. (2) Later, $P$. ovisternata was claimed a junior synonym of Pachastrella monilifera by Topsent (1902: 14; 1904: 93, 94). The systematic value of the mesotriaenes at specific level was considered low by Topsent, who assumed that these spicules occasionally 
appeared in Pachastrella from sporadic modifications in dichotriaenes which originated, in their turn, from occasional modifications in calthrops (Topsent, 1902, 1904). (3) The disregard of the systematic significance of the mesotriaenes which emerged from Topsent's interpretations brought Ferrer-Hérnandez (1914) to incorrectly record the name of $\boldsymbol{P}$. ovisternata for specimens lacking mesotriaenes, dichotriaenes and characteristic long oxeas. After re-examination, I came to the conclusion that the material described by FerrerHernández (1914) actually belongs to the species Pachastrella monilifera.

The illegitimacy of $\boldsymbol{P}$. ovisternata has been supported for a long time mainly because of a vague report on specimens bearing dichotriaenes and mesodichotriaenes. These specimens were at first regarded by Topsent $(1902: 14,17)$ as "peculiar" material belonging to $P$. abyssi Schmidt, 1870 , but, two years later, Topsent himself (1904) claimed synonymy of $\boldsymbol{P}$. abyssi and $\boldsymbol{P}$. monilifera. Mesodichotriaenes were envisaged by Topsent (1902, 1904) as spicules of sporadic occurrence, i.e. occasional results of haphazard modifications in calthrops and thus of no systematic value.

In contrast, most evidence indicates that mesodichotriaenes of $P$. ovisternata are a well established category of spicules: (1) They are always perfect in shape (Pl. IIc, d), while the occurrence of some malformations would be expected under Topsent's assumption. (2) In addition, a great variability in size occurs in the calthrops whereas the size is especially uniform in the mesotriaenes. (3) The arrangement of mesotriaenes in the sponge is different to that of the calthrops. Mesodichotriaenes are particularly confined to the inner choanosome, whereas calthrops indiscriminately occur everywhere in the sponge. (4) Finally, there are no other reports on specimens with mesotriaenes either in $P$. monilifera or in $P$. abyssi (cf. Schmidt, 1870, 1880; Carter, 1876; Sollas, 1888; Van Soest \& Stentoft, 1988). Calthrops and mesodichotriaene megascleres are further compared in Pl. IIb.

Therefore, the skeletal differences noted, mainly the presence of especially long oxeas and mesodichotriaenes, isolate and identify $P$. ovisternata from the remaining complex of species (P. moni- lifera $+P$. abyssi) as proposed by Topsent (1902, 1904). Consequently, Pachastrella ovisternata Von Lendenfeld, 1894 is herein claimed as a valid species, clearly different from $P$. monilifera.

It is also worth noting that $P$. ovisternata resembles the Indian species Yodomia perfecta Dendy, 1916, which has a spicule complement of long oxeas, mesotriaenes, calthrops, amphiasters, microrhabdoid streptasters ("reduced streptasters" according to Dendy, 1916), and oval microstrongyles. $Y$. perfecta is only differentiated from $P$. ovisternata in minor details of its skeleton, such as the absence of dichotriaenes and the occurence of tetracladose mesotriaenes in addition to the dichotomous ones.

The genus Yodomia Lebwohl, 1914, erected for Yodomia ijimai, was modified by Dendy (1916) in order to include a second species, Yodomia perfec$t a$. Both species appear to be very rare, since they have been recorded only once (Sea of Japan: Lebwohl, 1914) and twice (Indian Ocean -Saya de Malha-: Dendy, 1916; Burton, 1959), respectively. Some skeletal features of $Y$. ijimai, such as the presence of long-shafted triaenes (rhabdome measuring up to $2200 \mu \mathrm{m}$ and undeveloped clads), mesotriaenes with undivided clads, absence of microrhabdoid streptasters, and presence of curved microstrongyles with occasional oxeote ends (presumably arising from microxeas and non-homologous with the oval microstrongyles), suggest that this species is not closely related to $Y$. perfecta. In contrast, $Y$. perfecta and $P$. ovisternata are noted to be very closely related, in spite of having traditionally belonged to different genera.

In a discussion on the relationships concerning $P$. ovisternata, the monospecific genus Brachiaster Wilson, 1925, characterized by the presence of mesotriaenes transforming to desmas, can not be obviated. This genus was formerly regarded as a lithistid "incertae sedis" (Wilson, 1925), later redescribed in Pachastrellidae (Lévi \& Lévi, 1989) and recently reclassified into Lithistida Tetracladina (Levii, 1991). The presence in Brachiaster of some skeletal characters also present in typical pachastrellids, such as diversely branched mesotriaenes (although becoming desmas), oval microstrongyles and metasters, require careful considera- 
tion. In my opinion, and taking into account the fact that species such as Yodomia perfecta and Pachastrella ovisternata were overlooked by Lévi (1991) in his discussion about the relationships of Brachiaster, it would be advisable to reconsider the possible systematic relocation of this genus in the Pachastrellidae.

\section{Phylogenetic analysis}

The parsimony analysis was seen to be the best way to tackle the obscure relationships between the above-mentioned species. The study was carried out in three phases. The first phase analyzed the relationships among the pachastrellid genera, including Brachiaster. The second phase explored the possible generic placement of the problematic species, such as Yodomia ijimai, Yodomia perfecta, and Pachastrella ovisternata. The third phase examined the relationships between several species traditionally assigned to three different genera (Pachastrella, Brachiaster, and Yodomia), based on the results of the preliminary parsimony analyses.

\section{Outgroup selection}

A multiple outgroup was utilized in all analyses, since it is the most stringent test of the ingroup monophyly (Bergquist \& Kelly-Borges, 1991).

According to the traditional family diagnoses (e.g., Lévi, 1973), members of Theneidae could be thought to be the most appropriate outgroup for tackling the relationships among pachastrellid genera. However, calthropellid and stellettid genera were used to elaborate the outgroup. The occurrence of short-shafted mesotriaenes along with calthrops in some calthropellids, as well as the occurrence of streptasters in some stellettids (e.g., genus Stryphnus), were considered very useful features in ascertaining the homoplasous or homologous nature of such characteristics in Astrophorida.

The same reasoning was applied in the analysis at specific level and, thus, the subgroup consisting of Triptolemus-Stoeba was chosen as outgroup (rather than the subgroup consisting of
Poecillastra-Sphinctrella), to solve the relationships among Brachiaster simplex, Pachastrella monilifera, P. echinorhabda Pulitzer-Finali, 1973, $P$. ovisternata, and Yodomia perfecta. This multiple outgroup consisted of all four species belonging to Triptolemus along with Stoeba spp. (defined at generic level). Such a heterogeneous set is allowed, since "the outgroup comparisons need not be constrained by nomenclatural rank or Linnean hierarchical structure"' (Watrous \& Wheeler, 1981).

\section{Taxonomic background}

All taxa included in the analyses as well as some discarded taxa are briefly diagnosed and discussed below.

Ingroup genera:

Poecillastra Sollas, 1888: Pachastrellidae having oxeas, and calthrops, or pseudocalthrops as megascleres. Microscleres consist of microxeas in a single category and several types of streptasters with long and thin actines. Tetraxon spicules occur everywhere in the choanosome.

Characella Sollas, 1888: Pachastrellidae with a spicule complement similar to Poecillastra, but where tetraxons are restricted to subectosomal locations and two categories of microxeas always occur. Some authors (e.g., Pulitzer-Finali, 1983; Van Soest \& Stentoft, 1988) doubt the validity of this genus, but no complete study has been made in this matter. I have examined holotypes and material belonging to Characella pachastrelloides and $C h$. tripodaria, noting that the location of tetraxons was always restricted to peripheral choanosome. Sphinctrella Schmidt, 1870: Pachastrellidae whose oxeas are divided into two categories according to their choanosomal or ectosomal location. Calthrops or pseudocalthrops are restricted to the peripheral choanosome. Microscleres consist of one or several kinds of streptasters and one or two categories of microxeas. Oscules are grouped in exhalant areas surrounded by palisades of ectosomal oxeas.

Stoeba Sollas, 1888 (sensu Dendy, 1905): Pachastrellidae with calthrops or pseudocalthrops partially or completely replaced by short-shafted 
dichotriaenes (as, for instance, in Stoeba extensa Dendy, 1905 or St. natalensis Burton, 1926). Oxeas are absent. Microscleres are exclusively a single type of sanidaster with degenerate actines, located in an ectosomal layer. Endolithic or parasitic habit characterizes species of this genus.

Triptolemus Sollas, 1888: Parasitic Pachastrellidae whose tetraxons are exclusively short-shafted mesotriaenes with clads diversely branched. Oxeas may be absent in all species (according to Sarà, 1959), since those formerly described in Triptolemus intextus (Carter, 1876) (=T. parasiticus Carter, 1876, sensu Lévi \& Lévi, 1983) and T. cladosus Sollas, 1888 presumably belonged to the host sponges. Microscleres are streptasters, including degenerate forms in species such as $T$. cladosus, (according to Lévi \& Lévi, 1983: 153), T. simplex Sarà, 1959, and $T$. intextus. Microxeas are present in the species $T$. cladosus and $T$. incertus Kirkpatrick, 1903.

Pachastrella Schmidt, 1868: Pachastrellidae whose megascleres are oxeas and calthrops or pseudocalthrops. Microscleres consist of oval microstrongyles and several kinds of streptasters including degenerate forms. The presence of mesotriaenes in some species, presumably belonging to this genus, is examined further below.

Brachiaster Wilson, 1925: Monospecific genus whose megascleres are styloxeas, short-shafted mesotriaenes with clads diversely branched and desmas with mesotriaene crepis (named mesotriders, according to Reid, 1970). Short-shafted dichocalthrops, transforming to desmas, may be present or absent (Wilson, 1925; Lévi \& Lévi, 1989). Microscleres are oval microstrongyles and metasters.

\section{Outgroup genera:}

Pachastrissa Von Lendenfeld, 1903: Calthropellidae with oxeas, calthrops, and regular euasters (according to Von Lendenfeld, 1903; Lévi, 1973). Short-shafted mesotriaenes with unbranched clads are present in some species, such as Pachastrissa pathologica (Schmidt, 1868) and $P$. inopinata (Pulitzer-Finali, 1983).

Calthropella Sollas, 1888: Calthropellidae with calthrops and regular euasters. Oxeas are absent. After the application of the criteria of Von Lenden- feld and Lévi, typical species remaining in this genus in the Atlantic-Mediterranean region are Calthropella stelligera (Schmidt, 1868), C. recondita Pulitzer-Finali, 1973, and C. simplex.

Pachataxa De Laubenfels, 1936: Calthropellidae with calthrops, regular euasters and characteristic aberrant euasters displaying microrhabdoid shape (sometimes named ataxasters). Oxeas are absent. Short-shafted mesotriaenes occur in some species such as Pachataxa enigmatica Lévi \& Lévi, 1983, but they are absent in $P$. lithistina (Schmidt, 1880) and $P$. lutea Pulitzer-Finali, 1986.

Stryphnus Sollas, 1888: Stellettidae whose megascleres are long-shafted triaenes and oxeas. Microscleres consist of euasters as well as streptasters.

\section{Discarded genera:}

Indeed, it would be interesting to include in the analysis of the pachastrellid relationships some controversial genera (mentioned below), but this task would take too long and would complicate this study enormously. These genera are discussed below to provide a better understanding of the problematic taxonomic background.

Dercitus Gray, 1867: This genus with toxas and massive habit, is, in my personal opinion, different from Stoeba. The shape of the microrhabdoid microscleres is the main support for the traditional assumed identity between Dercitus and Stoeba. However, the microrhabdoid shape may be deceptive in establishing relationships, since it is a morphological convergence which may be seen in microxeas (e.g., Characella pachastrelloides), streptasters (e.g., Triptolemus simplex, Pachastrella echinorhabda) and even in euasters (e.g., in species of Pachataxa: Topsent, 1897; De Laubenfels, 1936). As far as the presence of toxas is concerned, it must be conceded that this is an enigmatic feature whose relationship with the remaining microsclere types in Astrophorida is unclear; it may be important from an evolutionary point of view, but it is uninformative in a parsimony analysis. The alternative taxonomic opinion, viz. both genera should be separated, has been postulated previously by authors such as Dendy (1905), Burton (1926), and Vacelet \& Vasseur (1971), whereas most contemporary authors do not make such a generic distinc- 
Table I. General data matrix. Lowercase letters indicate character states, positive symbols (+) indicate taxa included in each analysis, negative symbols (-) correspond to taxa and/or characters not used in the analyses. Characters $1-11$ were used in the analyses at the generic level and characters $2,4,5,9,10,12-16$ in the analyses at the specific level. For explanation of the characters, see text.

\begin{tabular}{|c|c|c|c|c|c|c|c|c|c|c|c|c|c|c|c|c|c|}
\hline \multirow[t]{2}{*}{ OTUS } & \multicolumn{16}{|c|}{ CHARACTERS } & \multirow{2}{*}{$\frac{\text { TREES }}{\text { T1 T2 T3 T4 }}$} \\
\hline & 1 & 2 & 3 & 4 & 5 & 6 & 7 & 8 & 9 & 10 & 11 & 12 & 13 & 14 & 15 & 16 & \\
\hline STRYPHNUS & $\mathbf{a}$ & $\mathbf{b}$ & $\mathbf{b}$ & $\mathbf{a}$ & $\mathbf{a}$ & c & $\mathbf{b}$ & $\mathbf{b}$ & $\mathbf{a}$ & $\mathbf{a}$ & $\mathbf{a}$ & - & - & - & - & - & +++- \\
\hline PACHASTRISSA & $\mathbf{a}$ & $\mathbf{b}$ & $\mathbf{a}$ & $\mathbf{b}$ & $a b$ & $\mathbf{a}$ & $\mathbf{a}$ & $\mathbf{b}$ & $\mathbf{a}$ & $\mathbf{a}$ & d & - & - & - & - & - & +++- \\
\hline$P A C H A T A X A$ & $\mathbf{a}$ & $\mathbf{a}$ & $\mathbf{a}$ & $\mathbf{a b}$ & $\mathbf{a b}$ & $\mathbf{a}$ & $\mathbf{a}$ & c & $\mathbf{a}$ & $\mathbf{a}$ & d & - & - & - & - & - & +++- \\
\hline CALTHROPELLA & $\mathbf{a}$ & $\mathbf{a}$ & $\mathbf{a}$ & $\mathbf{b}$ & $\mathbf{a}$ & $\mathbf{a}$ & $\mathbf{a}$ & $\mathbf{b}$ & $\mathbf{a}$ & $\mathbf{a}$ & d & - & - & - & - & - & +++- \\
\hline POECILLASTRA & $\mathbf{a}$ & $\mathbf{b}$ & $\mathbf{a}$ & $\mathbf{b}$ & $\mathbf{a}$ & $\mathbf{a b}$ & $\mathbf{b}$ & $\mathbf{a}$ & $\mathbf{b}$ & $\mathbf{a}$ & c & - & - & - & - & - & +++- \\
\hline CHARACELLA & $\mathbf{a}$ & $\mathbf{b}$ & $\mathbf{b}$ & $\mathbf{b}$ & $\mathbf{a}$ & $\mathbf{a b}$ & b & $\mathbf{a}$ & bc & $\mathbf{a}$ & c & - & - & - & - & - & +++- \\
\hline SPINCTRELLA & $\mathbf{a}$ & c & b & $\mathbf{b}$ & $\mathbf{a}$ & $\mathbf{a}$ & b & $\mathbf{a}$ & bc & $\mathbf{a}$ & c & - & - & - & - & - & +++- \\
\hline STOEBA & b & $\mathbf{a}$ & $\mathbf{a}$ & $\mathbf{b}$ & $\mathbf{a}$ & $\mathbf{a}$ & c & $\mathbf{a}$ & $\mathbf{a}$ & $\mathbf{a}$ & $\mathbf{a}$ & c & $\mathbf{a}$ & $\mathbf{a}$ & $\mathbf{b}$ & c & $++t+$ \\
\hline TRIPTOLEMUS & $\mathbf{b}$ & $\mathbf{a b}$ & $\mathbf{a}$ & $\mathbf{a}$ & $\mathbf{b}$ & $\mathbf{a}$ & bd & $\mathbf{a}$ & $\mathbf{a b}$ & $\mathbf{a}$ & ac & - & - & - & - & - & +++- \\
\hline PACHASTRELLA - 1 & $\mathbf{a}$ & $\mathbf{b}$ & $\mathbf{a}$ & $\mathbf{b}$ & $\mathbf{a}$ & $\mathbf{a}$ & d & $\mathbf{a}$ & $\mathbf{a}$ & $\mathbf{b}$ & $\mathbf{b}$ & - & - & - & - & - & ++-- \\
\hline PACHASTRELLA - 2 & $\mathbf{a}$ & $\mathbf{b}$ & $\mathbf{a}$ & $\mathbf{b}$ & $a b$ & $\mathbf{a}$ & d & $\mathbf{a}$ & $\mathbf{a}$ & $\mathbf{b}$ & $\mathbf{b}$ & - & - & - & - & - & --+- \\
\hline BRACHIASTER simplex & $\mathbf{a}$ & $\mathbf{b}$ & $\mathbf{a}$ & $a b$ & c & $\mathbf{a}$ & b & $\mathbf{a}$ & $\mathbf{a}$ & $\mathbf{b}$ & $\mathbf{b}$ & $\mathbf{a}$ & c & $\mathbf{b}$ & $\mathbf{a}$ & $\mathbf{a}$ & ++++ \\
\hline YODOMIA ijimai & $\mathbf{a}$ & $\mathbf{b}$ & $\mathbf{a}$ & b & b & c & b & d & c & $\mathbf{a}$ & $\mathrm{c}$ & - & - & - & - & - & -++- \\
\hline Yodomia perfecta & $\mathbf{a}$ & $\mathbf{b}$ & a & $\mathbf{b}$ & b & $\mathbf{a}$ & d & $\mathbf{a}$ & $\mathbf{a}$ & $\mathbf{b}$ & b & $a b$ & $\mathbf{c}$ & b & $\mathbf{b}$ & $\mathbf{a}$ & -+-+ \\
\hline Pachastrella ovisternata & $\mathbf{a}$ & $\mathbf{b}$ & $\mathbf{a}$ & $\mathbf{b}$ & b & $\mathbf{a}$ & d & $\mathbf{a}$ & $\mathbf{a}$ & $\mathbf{b}$ & $\mathbf{b}$ & a & $\mathbf{b}$ & b & $\mathbf{b}$ & $\mathbf{a}$ & -+-+ \\
\hline Pachastrella monilifera & - & $\mathbf{b}$ & - & b & $\mathbf{a}$ & - & - & - & $\mathbf{a}$ & $\mathbf{b}$ & - & $\mathbf{a}$ & $\mathbf{a}$ & b & b & $\mathbf{a}$ & ---+ \\
\hline Pachastrella echinorhabda & - & $\mathbf{b}$ & - & $\mathbf{b}$ & $\mathbf{a}$ & - & - & - & $\mathbf{a}$ & $\mathbf{b}$ & - & $\mathbf{b}$ & $\mathbf{a}$ & b & c & $\mathbf{a}$ & ---+ \\
\hline Triptolemus simplex & - & $\mathbf{a}$ & - & $\mathbf{a}$ & b & - & - & - & a & $\mathbf{a}$ & - & c & c & c & b & b & ---+ \\
\hline Triptolemus intextus & - & $?$ & - & $\mathbf{a}$ & $\mathbf{b}$ & - & - & - & $\mathbf{a}$ & $\mathbf{a}$ & - & c & c & $\mathbf{b}$ & $\mathbf{b}$ & b & ---+ \\
\hline Triptoleus incertus & - & $\mathbf{a}$ & - & $\mathbf{a}$ & b & - & - & - & b & $\mathbf{a}$ & - & c & c & $\mathbf{b}$ & $\mathbf{a}$ & $\mathbf{a}$ & ---+ \\
\hline Triptolemus cladosus & - & $?$ & - & $\mathbf{a}$ & b & - & - & - & $\mathbf{b}$ & $\mathbf{a}$ & - & c & c & $\mathbf{b}$ & b & a & ---+ \\
\hline
\end{tabular}

tion. Both opinions are debatable and it is obvious that this systematic matter is far from being completely solved. In any case, the elimination of this genus from the present analysis was thought advisable so as to avoid further complications, as it hardly affects either the aims or the conclusions of this study.

Lamellomorpha Bergquist, 1968: Monospecific genus erected for Lamellomorpha strongylata Bergquist, 1968 and located by the original author in the dustbin order Epipolasida. The megasclere complement lacks tetraxon spicules and consists exclusively of flexuous strongyles. Microscleres are two kinds of degenerate (microrhabdoid) streptasters along with amphiaster-metaster forms having welldeveloped actines. Such microscleres could correspond to a very modified pachastrellid, but for the present the genus is excluded from the analysis due to its uncertain status.

Acanthotriaena Vacelet, Vasseur \& Lévi, 1976: Monospecific genus erected for the enigmatic spe- cies Acanthotriaena cripta Vacelet, Vasseur \& Lévi, 1976. The spicule complement consists of acanthodichotriaenes, spirasters, rhaphides and perhaps, small oxeas. In spite of being formerly described in the Pachastrellidae, the relationships between this genus and the remaining pachastrellids analyzed here are very obscure.

Nethea Sollas, 1888: Artificial genus erected to contain species having calthrops with underdeveloped actines. It was rejected in Lévi's classification (1973) and questioned by other authors (e.g., Pulitzer-Finali, 1983). In my opinion, this genus ought to be formally abandoned and its species reclassified in other pachastrellid genera: Nethea nana (Carter, 1880) and N. amygdaloides (Carter, 1876) clearly belong to the genus Poecillastra; Nethea dissimilis Sarà, 1959 probably belongs to the genus Stoeba.

Character analysis

A total of sixteen characters were used in the dif- 
ferent analyses (Table I). Characters 1-11 were utilized for the analyses at generic level, whereas characters $2,4,5,9,10,12-16$ were utilized in the analyses at specific level. Most of these characters concern skeletal features, since other characters, such as color, consistence, tactile surface and so on, have unknown evolutionary importance. All characters were unweighted in order to avoid subjective evaluations. Uninformative characters were rejected, or reinterpreted when possible, as character states. A question mark indicates a doubtful character state in an OTU (Operational Taxonomic Unit).

Multiple character states were utilized, when necessary, to introduce into the analysis the variability inherent in supraspecific taxa (genera, in this case). Multiple states were first treated under the hypothesis of "uncertainty" and then as "polymorphisms" (= variability, not Dollo characters). The states assigned to the terminal taxa in the cladogram, obtained under the hypothesis of uncertainty, are expected to be states of diagnostic value at generic level since they minimize the tree length (monomorphic ancestral state). Conversely, those states relegated to the condition of possible assignments (less parsimonious) will lack diagnostic value at generic level, since they would correspond to apomorphies exclusively arising in only a few species of the genus.

The use of multiple states facilitates the addition of new or controversial species (in this case Yodomia ijimai, Yodomia perfecta, and Pachastrella ovisternata) to a supraspecific system, even without adding new characters. This procedure offers an exploratory approach to the generic relationships of these species. Moreover, the addition of new taxa constitutes an intuitive method to check the robustness of the previously inferred classification (Sokal et al., 1992).

No character was polarized in the study at the generic level, since the relationships between the outgroup and the ingroup were assumed "a priori", to be either unsolved or poorly known. It would be actually difficult to logically support any given polarity. At the specific level in the study, the ancestral condition of the characters was assumed, when possible, according to the states found at the internal nodes in the generic cladogram. Assumed ancestors were never included in the searches.

\section{Characters were as follows:}

1. Habit: Endolithic and parasitic habits (1b) characterize the genera Stoeba and Triptolemus, whereas the remaining taxa lack this trend in habit (1a). 2. Oxeas: Present in a single category in most genera (2b). Oxeas are divided into two categories (ectosomal and choanosomal) in Sphinctrella (2c). Oxeas are absent (2a) in Stoeba and the outgroup genera Pachataxa and Calthropella (sensu Von Lendenfeld, 1903; Lévi, 1973). They are also absent in Triptolemus incertus and $T$. simplex, but its presence is doubtful in $T$. cladosus and $T$. intextus (e.g., Sollas, 1888; Sarà, 1959). The presence of a single category of oxeas was assumed to be the ancestral condition in the analysis at the specific level. 3. Tetraxon location: Tetraxon spicules may occur either dispersed in the choanosome (3a) or restricted to choanosomal peripheral zones (3b), as is noted in species of Characella, Sphinctrella, and Stryphnus.

4. Calthrops and calthropoid spicules: Calthrops or calthropoid spicules (including short-shafted dichotriaenes, e.g., in Characella or Stoeba) are present in most taxa (4b). They are always absent in Triptolemus (4a). However, their presence is subject to intraspecific variation in Brachiaster simplex (cf. Wilson, 1925; Lévi \& Lévi, 1989). They display interspecific variation in Pachataxa, i.e., they are absent in Pachataxa enigmatica and present in $P$. lithistina and $P$. lutea. The state " $4 \mathrm{~b}$ " was assumed to be the ancestral condition for this character in the analysis at the specific level.

5. Short-shafted mesotriaenes: Mesotriaenes are present (5b) in all species of Triptolemus, Yodomia ijimai, Yodomia perfecta, Pachastrella ovisternata, and some species of Pachastrissa, such as $\boldsymbol{P}$. pathologica (Pl. IV a-d) and $P$. inopinata. Mesotriaenes, transforming to mesotrider desmas, occur in Brachiaster (5c). Mesotriaenes are lacking in the remaining taxa (5a). The state " $5 a$ " was assumed to be the ancestral condition in the analysis at the specific level. 

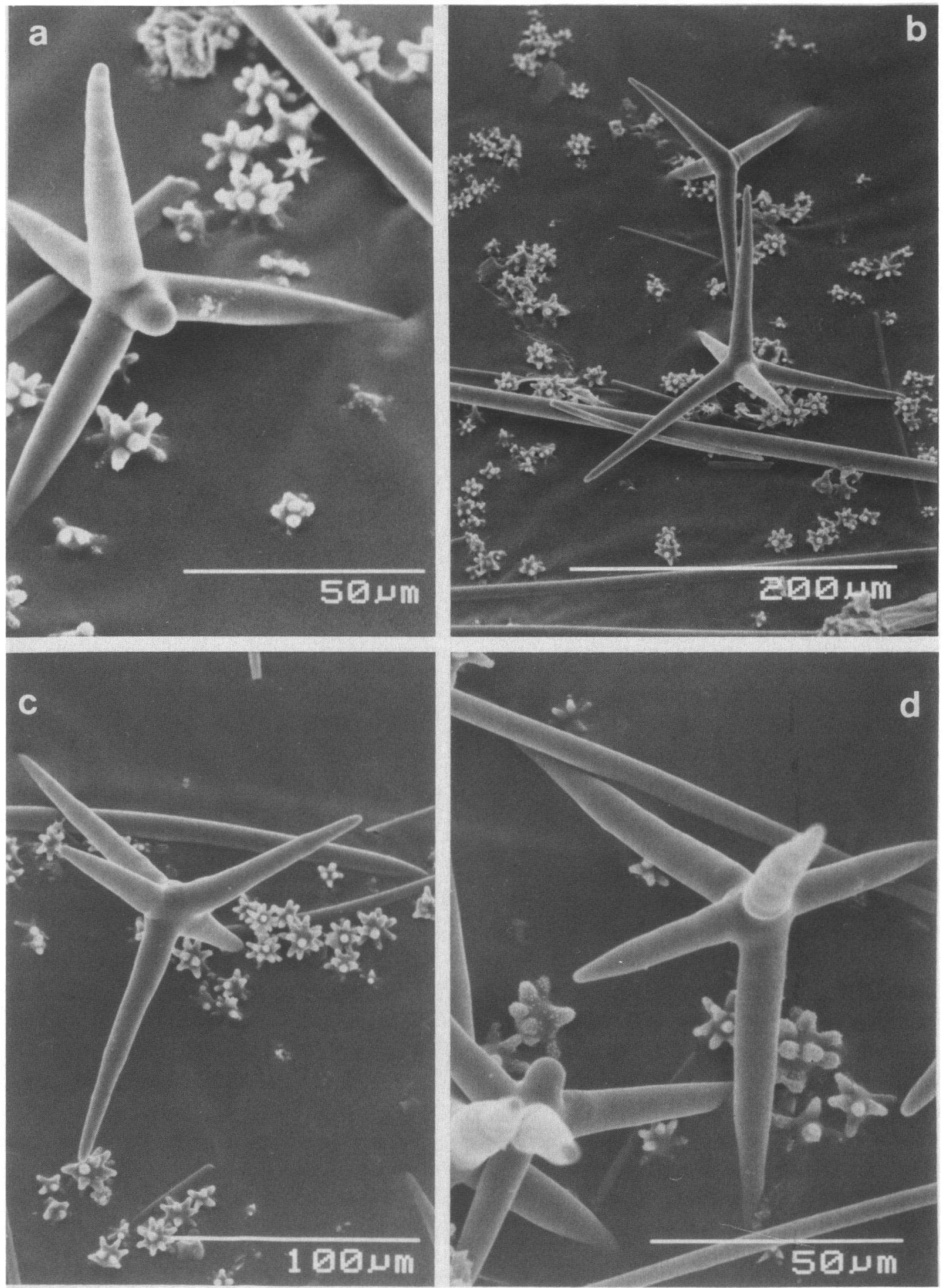

Plate IV. Tetraxon spicules of Pachastrissa pathologica: (a) mesotriaene with underdeveloped actine (mesocalthrops), (b) calthrops and mesotriaene with well-developed actines, (c) well-developed mesotriaene (mesocalthrops), (d) well-developed mesocaltrops and underdeveloped form (left lower corner). 
6. Long-shafted triaenes: According to the traditionally accepted diagnosis of the family Pachastrellidae (Lévi, 1973), these spicule types ought to be absent (6a). However, anatriaenes have been described in some pachastrellid species (6b), such as Characella tripodaria (= Sphinctrella linaresi), Poecillastra armata Hanitsch, 1895 and Poecillastra rudiastra. The presence of long-shafted orthoplagiotriaenes (6c) characterizes the genus Stryphus and they also occur in Yodomia ijimai.

7. Streptasters: Absent in all calthropellid genera (7a). They are regular forms with long, thin actines, and occur in Poecillastra, Characella, Sphinctrella, Brachiaster, some species of Triptolemus, and the outgroup Stryphnus (7b). They are exclusively forms with degenerate (reduced) actines (7c) in Stoeba. Both morphologies simultaneously occur in Pachastrella and some species of Triptolemus (7d).

8. Euasters: These spicules are absent in all ingroup taxa (8a). Euasters with a regular shape occur in all outgroup genera (8b), except in Pachataxa, where they are present together with degenerate forms (sometimes named ataxasters) (8c). Degenerated euasters (under the name of acanthosphaera) occur in Yodomia ijimai (8d).

9. Microxeas: Absent in most genera (9a). They occur as a single category (9b) in Poecillastra, Yodomia ijimai, Triptolemus incertus and T. cladosus. Most species of Characella and Sphinctrella display two categories of microxeas (9c), although sometimes only one category is found because of the intraspecific and/or interspecific variability. Absence of microxeas was assumed to be the ancestral condition at the specific level.

10. Oval microstrongyles: Present in all species of Brachiaster, Pachastrella, and in Yodomia perfecta (10b). The remaining species included in the analyses lack this spicule (10a). The "microrhabds" of Characella pachastrelloides or Yodomia ijimai (sometimes named microstrongyles) are assumed to be non-homologous spicules of the oval microstrongyles (cf. Dendy, 1916), since they are longer, curved, and occasionally display oxeote ends indicating their origin from microxeas. In the same way, degenerate streptasters of Stoeba and Pachastrella, usually referred to as microrhabds or micro- strongyles in the literature, ought to be terminologically differentiated from both above-mentioned types. The shape of the microrhabd is clearly a convergent morphology for several lines of microscleres (Wiedenmayer, 1977) and, thus, the use of the ambiguous term "microrhabd" ought to be avoided.

The results of the generic cladograms indicated that presence/absence of oval microstrongyles is a very consistent character (Consistency Index $=1$, Retention Index = 1). This fact allows us to take for granted the presence of microstrongyles as an irreversible apomorphy for the ingroup (analysis at specific level).

11. Ectosomal felt: The ectosome is reinforced for different kinds of microscleres. Streptasters are the principal spicules in the felt of Stoeba, Triptolemus intextus, $T$. simplex, and the outgroup genus Stryphnus (11a). Oval microstrongyles make up the ectosomal layer in Pachastrella, Brachiaster, $Y$. perfecta, and $P$. ovisternata (11b). Microxeas (or derived forms) are the principal spicules in the felt of Characella, Poecillastra, Sphinctrella, some species of Triptolemus ( $T$. cladosus, $T$. incertus) and Yodomia ijimai (11c). Euasters reinforce the ectosome of all three calthropellid genera of the outgroup (11d).

12. Habit (at specific level): This character is a remake of the character " 1 ", but used exclusively at the specific level. The endolithic-parasitic state (12c) has been retained as a characteristic feature of all species of Stoeba and Triptolemus. However, the non-endolithic-parasitic habit was split into massive (12a) and encrusting (12b) shapes. The ancestral condition is unknown, since the result of the generic cladogram does not allow us to deduce if the ancestral condition was massive or encrusting.

13. Maximal branching in mesotriaenes: Mesotriaenes of Brachiaster, those of Triptolemus, and Yodomia perfecta have clads reaching tri- or tetracladose states (13c), whereas they are dichotomous in Pachastrella ovisternata (13b). To assign a state of branching to species previously coded with the state " $5 \mathrm{a}$ " (= absence of mesotriaenes) is impossible. So then, a third hypothetical state, "13a" (absence of cladome) was assigned to those taxa with the state " $5 \mathrm{a}$ ". In this particular case, this way 


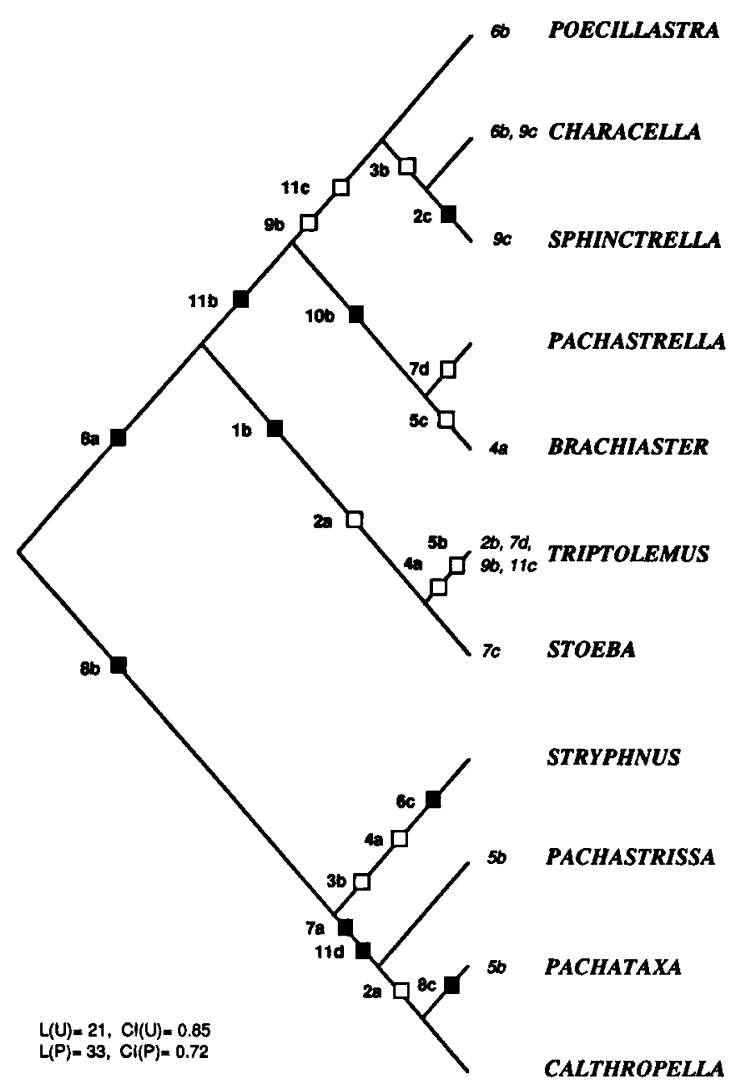

Fig. 2. Tree 1, displaying the inferred relationships according to the traditional concedts of the genus Pachastrella. The black squares indicate apomorphy, the open squares indicate homoplasy, numbers in italics indicate terminal polymorphism. L(U) $=$ tree length under the hypothesis of uncertainty for multiple states. $\mathrm{L}(\mathrm{P})=$ tree length under polymorphism hypothesis for multiple states. $\mathrm{CI}(\mathrm{U})=$ consistency index under uncertainty hypothesis. $\mathrm{CI}(\mathrm{P})=$ consistency index under polymorphism hypothesis.

to treat incompatible characters is considered to be more realistic than the use of question marks. The state " $13 a$ " was assumed to be the ancestral condition, obviously in congruence with the polarity of character 5.

14. Regular streptaster: Absent in Stoeba (14a). In most species, they are exclusively forms with long thin actines (14b), but in Triptolemus simplex they occur along with forms having short conical actines (14c). State 14b was assumed to be the ancestral condition.

15. Degenerate streptasters: Absent in Brachiaster and $T$. incertus (15a). In most species they occur in a single category (15b), although there are two morphological categories (under the names of elongated microrhabds and cylindrical acanthorhabds) in Pachastrella echinorhabda (15c). The ancestral condition could not be deduced from the results of the generic cladograms.

16. Streptaster categories in the ectosomal felt: A felt containing both degenerate and regular streptasters (16b) occurs in Triptolemus intextus and $T$. simplex. Stoeba has exclusively degenerate streptasters (16c). The remaining species lack streptasters in the felt (16a). The ancestral condition is unknown.

\section{Parsimony methods}

The "Paup 3.0 g" program analyses the unordered, ordered and irreversible characters under Fitch, Kluge \& Farris, and Camin-Sokal optimizations, respectively (Swofford, 1989). The branch-andbound method was used to yield the most parsimonious trees.

The bootstrap method (Felsenstein, 1985) was applied to obtain confidence limits on the phylogeny inferred at the specific level. Bootstrapping was first applied to the complete data matrix.

\section{Parsimony analysis results}

The relationships inferred for the pachastrellid genera are presented in tree 1 (Fig. 2). The output included another most parsimonious tree, but it displayed a politomy for all three subgroups of pachastrellids (Poecillastra-Characella-Sphinctrella, Pachastrella-Brachiaster, and TriptolemusStoeba). A consensus tree leaves the relationships among these three subgroups unsolved. The ambiguity in the relationships among the subgroups stems from the fact that it was not possible to order the character "11" unless speculative assumptions were taken. Note that in the input data (Table I), the presence of mesotriaenes was still not included in the generic concept of Pachastrella (OTU $=\mathbf{P a}$ chastrella-1).

An exploratory analysis of the generic assignation for Yodomia ijimai, Y. perfecta, and Pachastrella ovisternata is shown in tree 2 (Fig. 3). The parsimony analysis yielded three equally parsimonious trees. All three above-mentioned pacha- 


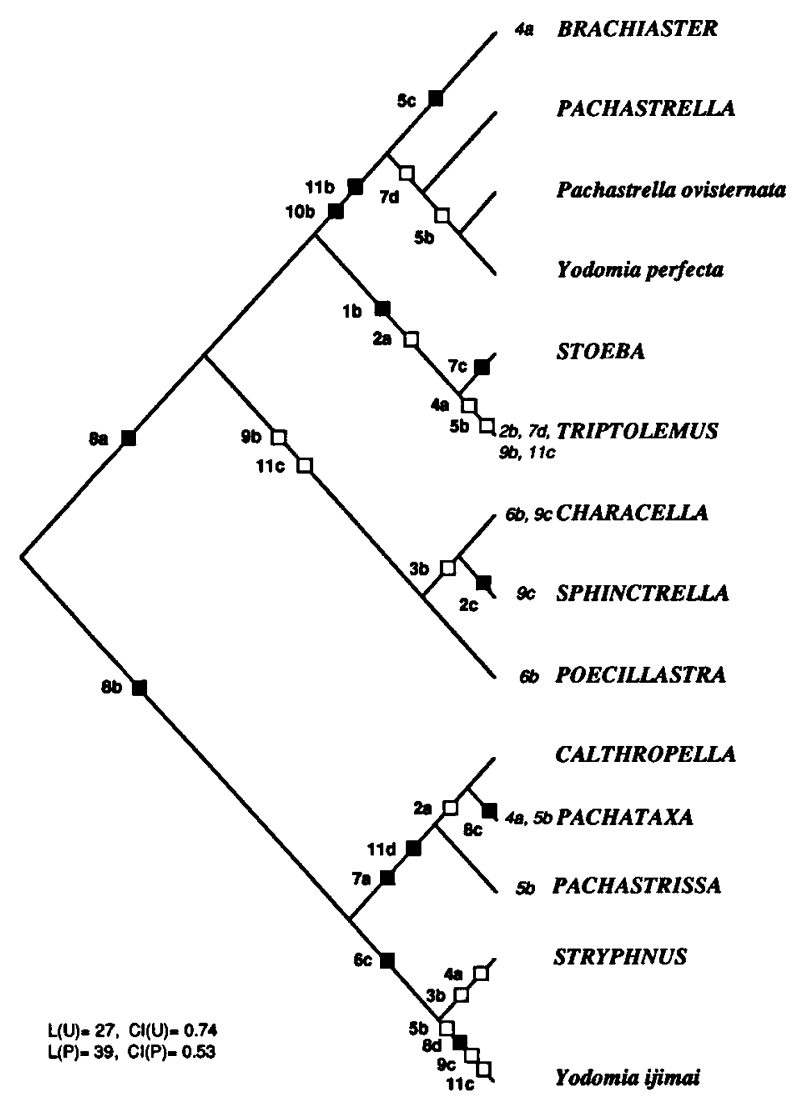

Fig. 3. Tree 2, displaying an approach to generic assignation for traditionally overlooked species with mesotriaenes. Note that polyphyly is in evidence for the genus Yodomia (sensu Dendy). Legend for symbols as in Fig. 2.

strellid subgroups were reconfirmed in this analysis, but a consensus tree again leaves the relationships among them unsolved. Note in the input matrix (Table I) that $Y$. perfecta and $P$. ovisternata are indistinguishable at the generic level (that is, using characters to diagnose genera) and closely related to Pachastrella regardless of mesotriaenes. The species $Y$. ijimai, on the other hand, is placed in the outgroup, far from $Y$. perfecta, in spite of having been traditionally included in the same genus.

The definitive relationships inferred for this set of genera are shown in tree 3 (Fig. 4). For this analysis, the presence of mesotriaenes in some species of the genus Pachastrella was considered (OTU $=P a$ chastrella-2) and besides, Yodomia was regarded as a monospecific genus exclusively containing $Y$. ijimai. Parsimony analysis yielded three equally



Fig. 4. Tree 3, displaying the inferred relationships after readjusting the generic concept of Pachastrella and Yodomia. Legend for symbols as in Fig. 2.

parsimonious trees. A consensus tree leaves the relationships between all three above-mentioned pachastrellid subgroups unresolved.

The consistency index (CI) for all of the cladograms is moderate or low, especially under the hypothesis of polymorphisms for the multiple character states. This fact, however, does not indicate a bad inference of the generic relationships. It must be conceded that demonstration of homoplasy by parsimony analysis is inherent in obtaining a low CI in the cladograms. A presumably homoplasous character has to be coded identically in all OTUs concerned in order to demonstrate that it has been acquired separately for them. This fact has a negative repercussion in the $\mathrm{CI}$ value of the cladogram. The decrease in CI under the hypothesis of polymorphisms is a logical consequence of the intra-OTU variability inherent to the characters 
Table II. Evaluation of the cladograms. NC = number of character; $\mathrm{T}=$ type: $\mathrm{U}=$ unordered, $\mathrm{O}=$ ordered, $\mathrm{I}=\mathrm{irreversible;}$ AP = plesiomorphic states assumed, IP = plesiomorphic states inferred from the cladogram; lowercase letters correspond to character states, question marks (?) indicate unknown character states; $\mathrm{CI}(\mathrm{U})=$ consistency index under the hypothesis of uncertainty for multiple states; $\mathrm{CI}(\mathrm{P})=$ consistency index under polymorphism hypothesis.

\begin{tabular}{|c|c|c|c|c|c|c|c|c|c|c|c|c|}
\hline \multirow[b]{3}{*}{$\mathrm{NC}$} & \multicolumn{7}{|c|}{ GENERIC LEVEL } & \multicolumn{5}{|c|}{ SPECIFIC LEVEL } \\
\hline & \multirow[b]{2}{*}{$\mathbf{T}$} & \multirow[b]{2}{*}{$\mathbf{A P}$} & \multirow[b]{2}{*}{ IP } & \multicolumn{2}{|c|}{ TREE 1} & \multicolumn{2}{|c|}{ TREE 3} & \multirow[b]{2}{*}{$T$} & \multirow[b]{2}{*}{$\mathbf{A P}$} & \multirow[b]{2}{*}{ IP } & \multicolumn{2}{|c|}{ TREE 4} \\
\hline & & & & $\mathrm{CI}(\mathrm{U})$ & $\mathbf{C l}(\mathbf{P})$ & CI(U) & $\mathrm{CI}(\mathrm{P})$ & & & & CI(U) & $\mathrm{CI}(\mathrm{P})$ \\
\hline 1 & $\mathbf{U}$ & $?$ & $\mathbf{a}$ & 1.00 & 1.00 & 1.00 & 1.00 & - & - & - & - & - \\
\hline 2 & $\mathrm{U}$ & $?$ & b & 0.66 & 0.50 & 0.66 & 0.50 & $\mathbf{U}$ & $\mathbf{a}$ & b & 1.00 & 1.00 \\
\hline 3 & $\mathrm{U}$ & $?$ & $\mathbf{a}$ & 0.50 & 0.50 & 0.50 & 0.50 & - & - & - & - & - \\
\hline 4 & $\mathbf{U}$ & $?$ & $\mathbf{b}$ & 0.50 & 0.25 & 0.50 & 0.25 & $\mathrm{U}$ & $\mathbf{b}$ & $\mathbf{b}$ & 1.00 & 0.50 \\
\hline 5 & $\mathrm{U}$ & $?$ & $\mathbf{a}$ & 1.00 & 0.50 & 0.50 & 0.33 & $\mathbf{U}$ & $\mathbf{a}$ & $\mathbf{a}$ & 0.66 & 0.66 \\
\hline 6 & $\mathbf{U}$ & $?$ & $\mathbf{a}$ & 1.00 & 0.66 & 1.00 & 0.66 & - & - & - & - & - \\
\hline 7 & $\mathbf{U}$ & $?$ & $\mathbf{b}$ & 1.00 & 0.75 & 1.00 & 0.75 & - & - & - & - & - \\
\hline 8 & 0 & $?$ & $?$ & 1.00 & 1.00 & 0.75 & 0.75 & - & - & - & - & - \\
\hline 9 & $\mathrm{U}$ & $?$ & $\mathbf{a}$ & 1.00 & 0.50 & 1.00 & 0.40 & $\mathbf{U}$ & $\mathbf{a}$ & $\mathbf{a}$ & 1.00 & 1.00 \\
\hline 10 & $\mathbf{U}$ & $?$ & $\mathbf{a}$ & 1.00 & 1.00 & 1.00 & 1.00 & I & $\mathbf{a}$ & $\mathbf{a}$ & 1.00 & 1.00 \\
\hline 11 & $\mathbf{U}$ & $?$ & $\mathbf{a}$ & 1.00 & 0.75 & 0.75 & 0.60 & - & - & - & - & - \\
\hline 12 & - & - & - & - & - & - & - & 0 & $?$ & b & 1.00 & 0.66 \\
\hline 13 & - & - & - & - & - & - & - & 0 & $\mathbf{a}$ & $\mathbf{a}$ & 0.50 & 0.50 \\
\hline 14 & - & - & - & - & - & - & - & 0 & b & b & 1.00 & 1.00 \\
\hline 15 & - & - & - & - & - & - & - & $\mathbf{U}$ & ? & b & 0.66 & 0.66 \\
\hline 16 & - & - & - & - & - & - & - & $\mathbf{U}$ & $?$ & $\mathbf{a}$ & 1.00 & 1.00 \\
\hline
\end{tabular}

with multiple states. The advantage of using multiple states under the hypothesis of polymorphisms is that this procedure permitted the detection of hidden homoplasies and reversions in a study at the generic level, which otherwise would be omitted by exclusively affecting some isolated species in each genus. If this variability is overlooked, the estimation of the character consistency might result in unrealistically high values (Table II).

Characters 1 (habit) and 10 (oval microstrongyles) were the most consistent at the generic level (Table II). Characters 4 (calthrops) and 5 (mesotriaenes) were noted to be the least consistent because of their intra-OTU variability and their homoplasous nature, respectively.

The relationships inferred for the set of species characterized by the presence of oval microstrongyles are shown in tree 4 (Fig. 5). The parsimony analysis yielded one single most parsimonious tree. A close relationship seems evident on the cladogram between all species included in the ingroup. The relationship detected in all analyses between Triptolemus and Stoeba provides a very interesting contribution to clarify the obscure relationships which have been so far shrouding the enigmatic genus Triptolemus.

It is worth noting that no bootstrap test detected statistically significant monophyly in the ingroup set, although a common linkage for all four species of Triptolemus was found $90 \%$ of the times. Such a percentage, although less than the $95 \%$ suggested by Felsenstein (1985), is large enough to be significant. In any case, the results of the bootstrap method ought to be regarded as approximative for two reasons: (1) tests were applied to data in which the homoplasous nature of some character states was intentionally overlooked, and (2) characters 5 and 13 are not fully independent of each other, and neither are characters 14,15 and 16 , although they are treated as stochastically independent in the resampling processes.

Table II shows characters 4 (calthrops) and 13 (maximal branching of the clads in mesotriaenes) as the least consistent at the specific level. Note that cladogram 4 (Fig. 5) indicates that mesotriaenes (5b) have arisen more than once in this set of spe- 


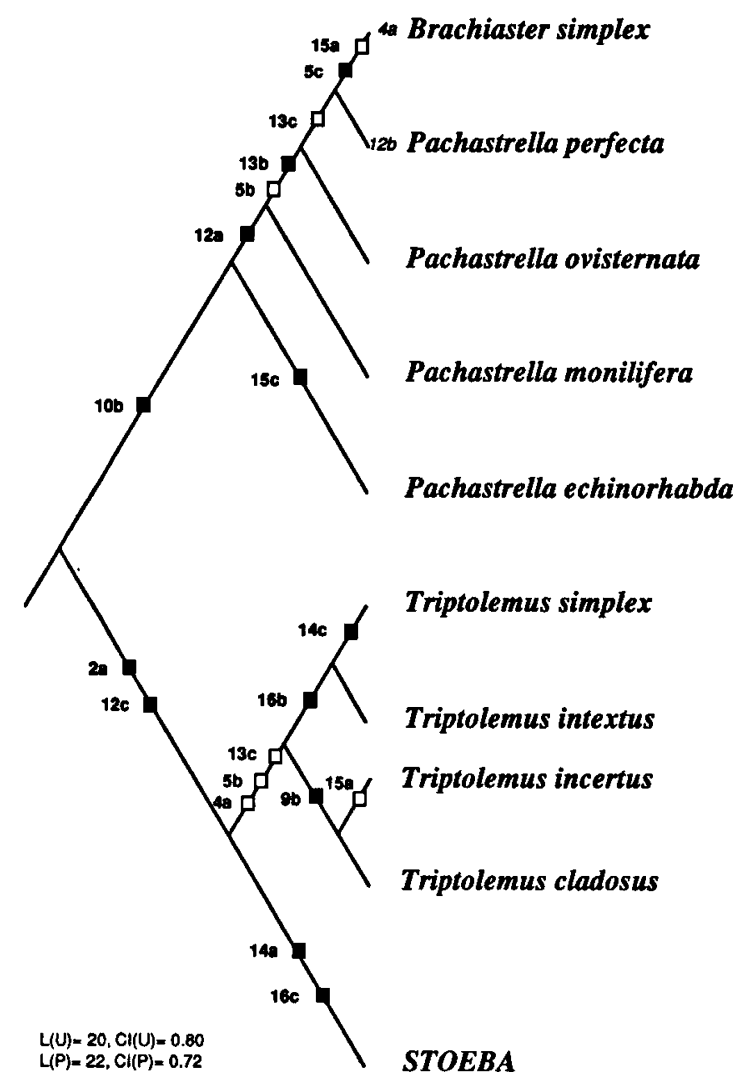

Fig. 5. Tree 4, displaying the specific relationships inferred for species of Pachastrella and Brachiaster. Note that the relationships are also well solved in the multiple outgroup. Legend for symbols as in Fig. 2.

cies. Parsimony analyses support Sarà's opinion (1959) that oxeas ought to be regarded as absent in all species of Triptolemus. Oxeas described by Carter (1876) in Triptolemus intextus $(=T$. parasiticus), probably belong to the host sponge Corallistes. If oxeas are assumed to be actually present in such species, they have to be regarded as character reversals.

\section{General discussion}

Parsimony analyses clearly indicate that the genus Yodomia, in the way diagnosed by Dendy (1916), is a polyphyletic taxon. Consequently, this genus ought to be used only in the strict sense of Lebwohl (1914), containing only the type species Yodomia ijimai, and the species Yodomia perfecta ought to be relocated in the genus Pachastrella, near Pachastrella ovisternata. The genus Yodomia (sensu Lebwohl, 1914) is a borderline genus between Pachastrellidae and Stellettidae, whose definitive location can not be ascertained from the analyses performed in this paper. In my view, it is closer to a stellettid genus (similar to Stryphnus, for instance) than to pachastrellid genera, although a new analyses mostly including stellettid taxa would be necessary to be absolutely certain on this matter. It is worth mentioning that the parsimony analysis always yielded trees in which Yodomia ijimai was related to Stryphnus, even if the acanthosphaeras were not assumed to be a type of reduced euasters.

The species set consisting of Brachiaster simplex, Pachastrella perfecta (formerly Yodomia), P. ovisternata, $P$. monilifera, and $P$. echinorhabda might be assumed to be a single taxonomic unity, but it does not have statistically significant monophyly. It must be conceded that the parsimony analysis lacks a sensitive method for distributing species in supraspecific ranks, and the usual procedure consists of assigning a new rank (clade) after each branching point on the tree. It is generally more useful to take an evolutionary attitude, constructing supraspecific taxa according to the degree of divergence between OTUs. So then, as far as the number of apomorphic states between nodes is concerned, three subgroups can be distinguished in this analysis $(P$. echinorhabda-P. monilifera, $P$. ovisternata-P. perfecta, and Brachiaster simplex). The state " $5 \mathrm{~b}$ " (presence of mesotriaenes) is one of the two apomorphies separating the first and the second subgroup and its consistency is very low at generic level. Thus, it would be advisable to keep both specific subgroups under the single generic name of Pachastrella.

As for the generic location of Brachiaster simplex, cladograms indicate that this OTU is separated from the related species at least for two apomorphies: " $5 \mathrm{c}$ " (presence of mesotriders) and "15a" (absence of degenerate streptasters). In this case, the number of apomorphies can not really prove whether or not this taxon indeed belongs to Pachastrella or should be considered as a different genus (although closely related to Pachastrella). It is 
worth noting, however, that the relationship between the mesotriaenes of Pachastrella (5b) and the mesotriders of Brachiaster (5c) is unclear. If the state " $5 b$ " (instead of " $5 c$ ") is assigned to Brachiaster, the analysis indicates that mesotriaenes are a shared homologue (synapomorphy) in both taxa. This fact strengthens the affinity between both taxa and it even introduces the possibility of a generic synonymy. However, there are other aspects involved in this matter, which merit careful examination: (1) only two specimens of Brachiaster are known (cf. Wilson, 1925; Lévi \& Lévi, 1989) and one of them, the holotype, notably macerated; (2) dichotriaenes becoming non-mesotrider desmas, described in the holotype, are absent in the recent specimen; (3) oxeas and microscleres, described in the recent specimen, were not found in the holotype. The lack of some small skeletal elements (microscleres) in the holotype may be tentatively attributed to its maceration state (cf. Wilson, 1925), but, in my view, this assumption is not convincing to explain the complete absence of long oxeas. In addition, the absence of dichotriaenes transforming to non-mesotrider desmas also remains unexplained in the recent specimen (Lévi \& Lévi, 1989). In a word, the true skeletal differences between both specimens remain enigmatic and, in my opinion, the assumed conspecific nature of both specimens should be regarded as an uncertainty. Therefore it seems advisable to keep the genus Brachiaster, as such, till further material produces more useful information.

In the same way, the description of new specimens would be necessary to clarify the matter concerning a possible identity between Pachastrella ovisternata and Pachastrella perfecta. Both species are only distinguished by two characters: (1) presence/absence of dichotriaenes in their respective spicule complements; (2) occurrence of multibranched clads in mesotriaenes of $P$. perfecta versus dichotomous clads in $\boldsymbol{P}$. ovisternata. Both presumably distinctive characters are not very reliable from a taxonomic point of view. Presenceabsence of dichotriaenes is subject to intraspecific variability in pachastrellid and calthropellid species, such as Characella pachastrelloides or Pachastrissa geodioides (Carter, 1876). As for the maximal state in branching of clads in mesotriaenes (character 13), it was found to be one of the least consistent characters in the analysis at the specific level (Table II). At first sight, the geographical separation between both species might be good evidence to warrant their specific separation. However, it is worth mentioning that other pachastrellid and calthropellid species, such as Sphinctrella annulata (Carter, 1880) (e.g. Topsent, 1897, 1904, 1928; Carter, 1880) or Pachastrissa geodioides (cf. Carter, 1876; Topsent, 1897, 1904; Desqueyroux-Faúndez, 1981), are simultaneously present in both Lusitanian and Indonesian-Philippine locations.

The parsimony analysis clearly indicated that the presence of mesotriaenes in calthropellids and pachastrellids is a homoplasy. Moreover, mesotriaenes seem to have arisen separately in Triptolemus and Pachastrella-Brachiaster, in spite of being closely related. Notwithstanding, it is possible that, in this particular case, the homoplasy might have resulted from genetic polymorphism (rather than from convergent evolution) that arises and persists through speciation events, segregating the same variants at different points on the tree (Felsenstein, 1983).

Short-shafted mesotriaenes correspond to a special morphology of tetraxon spicules, which has been independently acquired from calthrops (in Calthropellidae), short-shafted plagiotriaenes (e.g. Yodomia ijimai), and short-shafted orthodichotriaenes (e.g. Pachastrella, Triptolemus). Details of the shape displayed in mesotriaenes of different groups allow the establishment of morphological types corroborating the homoplasous nature detected in the parsimony analyses: (1) Spicules with clads undivided, equally long and arranged at equal angles (mesocalthrops) (PI. IVb, c, d); presence of a fifth clad usually underdeveloped (Pl. IV a, d) is characteristic; they occur in calthropellid species. (2) Short-shafted plagiomesotriaenes with undivided clads and a well-developed mesoactine (epirhabdome). As far as known, they occur exclusively in Yodomia ijimai. (3) Short-shafted mesotriaenes characterized by a well-developed epirhabdome and a diversely branched cladome arranged in upright position. Spicules with undivided clads can occur, but they are regarded as either immature or underdeveloped ontogenetic states. These 
spicules occur in some species of Pachastrella (P1. IIc, d) and in all species of Triptolemus. (4) Short-shafted orthotriaenes, diversely branched, becoming mesotriders. They occur in monotypic genus Brachiaster, but its relation with the abovementioned type (3) is unclear.

There is no satisfactory explanation for the shortage of records on pachastrellids and calthropellids with short-shafted mesotrianes. However, there are several possibly connected items that are worth considering: (1) No paleontological evidence in the fossil record indicates the existence of mesotriaenes prior to calthrops. (2) Short-shafted mesotriaenes are only present in genera and families characterized by the presence of calthrops or "pseudocalthrops". (3) Fossil desmas derived from mesotriaenes (mesotriders) do not exist, while numerous fossil desmas originating from calthrops do occur (e.g., De Laubenfels, 1955; Reid, 1970). (4) Surprisingly, desmas having a mesotriaene crepis occur exclusively in the recent monospecific genus Brachiaster Wilson, 1925 (Lévi \& Lévi, 1989; Lévi, 1991). (5) The epirhabdome or fifth actine was noted to be notably or slightly less developed than the rhabdome sensu stricto or the equivalent actine in all short-shafted mesotriaenes studied. In conclusion, most evidence suggests that the presence of the fifth actine or epirhabdome might be either a recent or relatively late evolutionary acquisition for the calthropoid spicules, although a detailed study involving abundant fossil material would be necessary to be certain on this assertion.

\section{Acknowledgements}

I am indebted to Dr. Jesús Benito from the Complutense University of Madrid for the opportunity to study this interesting specimen, and to Drs. S. Stone (BMNH, London), E. Kritscher (NMW, Wien), O. Soriano (MNCN, Madrid) and V. Rainieri (MSNG, Genoa) for the loan of material. I also thank Drs. R.W.M Van Soest (Zoölogisch Museum, Amsterdam), S.M. Stone (BMNH, London), Q. Ferreiro (Museu e Laboratório Zoológico, Coimbra), and D. Kühlmann (Zoologisches Museum, Berlin) for their help in the search for the type material. I also thank Dr. D. Byrne for correcting the English. The Technical staff of the Microscopy Service (Central University of Barcelona) are thanked for their friendly and efficient assistance. Special thanks are due to two anonymous reviewers, whose constructive comments have notably improved the manuscript.
This research was supported by a Generalitat of Catalunya grant and by the funds of "Fauna Ibérica-II" Project (CICYT PB89-0081).

\section{Literature cited}

Bergquist, P.R., 1968. The marine fauna of New Zealand: Porifera, Demospongiae, Part 1 (Tetractinomorpha and Lithistida). Mem. N.Z. oceanogr. Inst., 37 (=Bull. N.Z. Dep. scient. ind. Res., 188): 1-105.

Bergquist, P.R. \& M. Kelly-Borges, 1991. An evaluation of the genus Tethya (Porifera: Demospongiae: Hadromerida) with descriptions of new species of the Southwest Pacific. The Beagle, Rec. Northern Territ. Mus. Arts Sci., 8 (1): 37-72, pls. I-II.

Bowerbank, J.S., 1861. List of the British sponges. In: [R.] McAndrew's "List of marine invertebrate fauna". Rep. Br. Ass. Advmt. Sci., 30, London: 830-836, pl. 36.

Bowerbank, J.S., 1866. A monograph of the British Spongiadae, 2: 1-388 (Ray Society, London).

Burton, M., 1926. Description of South African sponges collected in the South African Marine Survey. Part I. Myxospongia and Astrotetraxonida. Rep. Fish. mar. biol. Surv. Un. S. Afr., 4: 1-29, pls. 1-6.

Burton, M., 1959. Sponges. Scient. Rep. John Murray Exped., 10(5): $151-281$.

Carter, H.J., 1876. Descriptions and figures of deep-sea sponges and their spicules, from the Atlantic Ocean, dredged up on board H.M.S. 'Porcupine' chiefly in 1869 (concluded). Ann. Mag. nat. Hist., (4) 18: 388-410, pls. XIV-XVI.

Carter, H.J., 1880. Report on specimens dredged up from the Gulf of Manaar and presented to the Liverpool Free Museum by Capt. W.H. Cawne Warren. Ann. Mag. nat. Hist., (5) 5: 437-457, pls. XVIII-XIX; (5) 6: 35-61, pls. IV-VI; (5) 6: 129-156, pls. VII-VIII.

Dendy, A., 1905. Report on the sponges collected by Professor Herdman at Ceylon in 1902. Report to the Government of Ceylon on the pearl oyster fisheries of the Gulf of Manaar, 3 (Suppl. 18): 57-246, pls. I-XVI (Royal Society, London).

Dendy, A., 1916. Report on the Homosclerophora and Astrotetraxonida collected by H.M.S. "Sealark" in the Indian Ocean. Trans. Linn. Soc. Lond., (2, Zool.), 17 (2): 225-271, pls. 44-48.

Desqueyroux-Faúndez, R., 1981. Révision de la collection d'éponges d'Amboine (Moluques, Indonésie) constituée par Bedot et Pictet et conservée au Muséum d'histoire naturelle de Genève. Revue suisse Zool., 88 (3): 723-764.

Felsenstein, J., 1983. Parsimony in systematics: biological and statistical issues. A. Rev. Ecol. Syst., 14: 313-333.

Felsenstein, J., 1985. Confidence limits on phylogenies: an approach using the bootstrap. Evolution, 39 (4): 783-791.

Ferrer-Hernández, F., 1914. Esponjas del Cantábrico. Parte 2a. III. Myxospongida. IV. Tetraxonida. V. Triaxonida. Trab. Mus. nac. Cienc. Nat. Madrid (Zool.), 17: 3-44. 
Gray, J.E., 1867. Notes on the arrangement of sponges, with the description of some new genera. Proc. Zool. Soc. London, 1867: 492-558, pls. XXVII-XXVIII.

Hanitsch, R., 1895. Notes on a collection of sponges from the West coast of Portugal. Proc. Trans. Lpool. biol. Soc., 9: 205-219, pls. XII-XIII.

Kirkpatrick, R., 1902. Descriptions of South African sponges. Mar. Invest. S. Afr., 1: 219-232, pls. I-III.

Kirkpatrick, R., 1903. Descriptions of South African sponges. Part II. Mar. Invest. S. Afr., 2: 171-180, pl. IV.

Laubenfels, M.W. de, 1936. A discussion of the sponge fauna of the Dry Tortugas in particular and the West Indies in general, with material for a revision of the families and orders of the Porifera. Publs. Carnegie Inst. Wash., 467 (= Pap. Tortugas Lab., 30): i-iii, 1-225, pls. 1-22, 1 map.

Laubenfels, M.W. de, 1955. Porifera. In: R.C. Moore (ed.), Treatise on invertebrate paleontology: E21-E122 (Univ. Kansas Press, Lawrence).

Lebwohl, F., 1914. Japanische Tetraxonida. I. Sigmatophora and II. Astrophora metastrosa. J. Coll. Sci. imp. Univ. Tokyo, 35 (2): 1-116, pls. I-IX.

Lendenfeld, R. von, 1894. Eine neue Pachastrella. Sber. Akad. Wiss. Wien (Mat.-nat. Classe, Abth. I), 103 (1): 439-441, pl. I.

Lendenfeld, R. von, 1903. Tetraxonia. Das Tierreich, 19: i-xv, 1-168.

Lévi, C., 1973. Systématique de la classe des Demospongiaria (Démosponges). In: P-P. Grassé (ed.), Traité de zoologie, 3 (1): 557-631 (Masson et Cie, Paris).

Lévi, C., 1991. Lithistid sponges from the Norfolk Rise. Recent and Mesozoic genera. In: J. Reitner \& H. Keupp (eds.), Fossil and recent sponges: 72-82 (Springer Verlag, Berlin, Heidelberg).

Lévi, C. \& P. Lévi, 1983. Éponges Tétractinellides et Lithistides bathyales de Nouvelle-Calédonie. Bull. Mus. natn. Hist. nat., Paris, (Sect. A, Sér. 4), 5 (1): 101-168, pls. I-XIII.

Lévi, C. \& P. Lévi, 1989. Spongiaires (MUSORSTOM 1 \& 2). In: J. Forest (ed.), Résultats des campagnes MUSORSTOM, 4. Mém. Mus. natn. Hist. nat., (A) 143: 25-103.

Pulitzer-Finali, G., 1973. Report on a collection of sponges from the Bay of Naples. I. Sclerospongiae, Lithistida, Tetractinellida, Epipolasida. Pubbl. Staz. zool. Napoli, 38: “'1970”: 328-354.

Pulitzer-Finali, G., 1983. A collection of Mediterranean Demospongiae (Porifera) with, in appendix, a list of the Demospongiae hitherto recorded from the Mediterranean Sea. Annali Mus. civ. Stor. nat. Giacomo Doria, 84: 445-621.

Pulitzer-Finali, G., 1986. A collection of West Indian Demospongiae (Porifera). In appendix, a list of the Demospongiae hitherto recorded from the West Indies. Annali Mus. civ. Stor. nat. Giacomo Doria, 86: 65-216.

Reid, R.E.H., 1970., Tetraxons and demosponge phylogeny. In: W.G. Fry (ed.), The biology of the Porifera. Symp. zool. Soc. London, 25: 63-89 (Academic Press, London/New York).

Rützler, K., 1978. Sponges in coral reefs. In: D.R. Stoddart \&
R.E. Johannes (eds.), Coral reefs: research methods: 299-313 (Unesco, Paris).

Sarà, M., 1959. Specie nuove di Demospongie provenienti da acque superficiali del Golfo di Napoli. Annuar. Ist. Mus. Zool. Univ. Napoli, 11 (7): 1-22, pl. I.

Schmidt, O., 1868. Die Spongien der Küste von Algier. Mit Nachträgen zu den Spongien des Adriatischen Meeres, Suppl. 3: i-iv, 1-44, pls. I-V (W. Engelmann, Leipzig).

Schmidt, O., 1870. Grundzüge einer Spongien-Fauna des Atlantischen Gebietes: i-iv, 1-88, pls. I-VI (W. Engelmann, Leipzig).

Schmidt, O., 1880. Die Spongien des Meerbusen von Mexico (und des Caraibischen Meeres), 2: 33-90, pls. V-X (G. Fischer, Jena).

Soest, R.W.M. van \& N. Stentoft, 1988. Barbados deep-water sponges. Stud. Fauna Curaçao, 70 (215): 1-175.

Sokal, R.R., J. Kim \& F.J. Rohlf, 1992. Character and OTU stability in five taxonomic groups. J. Classification, 9: 117-140.

Sollas, W.J. 1888. Report on the Tetractinellida collected by H.M.S. "Challenger" during the years 1873-76. Rep. scient. Results Voy. Challenger, (Zool.) 25 (63): i-clxvi, 1-458, pls. I-XLIV, 1 map.

Swofford, D.L., 1989. PAUP 3.0 g. Phylogenetic analysis using parsimony (user's manual): i-iii, 1-43 (Illinois Natural History Survey, Champaign).

Topsent, E., 1897. Spongiaires de la Baie d'Amboine. Voyage de MM. M. Bedot et C. Pictet dans l'Archipel malais. Revue suisse Zool., 4 (3): 421-487, pls. XVIII-XXI.

Topsent, E., 1902. Les Asterostreptidae. Bull. Soc. scient. méd. Ouest, 11 (2): 1-18.

Topsent, E., 1904. Spongiaires des Açores. Résult. Camp. scient. Prince Albert I, 25: [i-iii], 1-280, pls. I-XVIII, [281-316].

Topsent, E., 1928. Spongiaires de l'Atlantique et de la Méditerranée, provenant des croisières du Prince Albert Ier de Monaco. Résult. Camp. scient. Prince Albert I, 74: [i-v], 1-376, [377-399], pls. I-XI.

Vacelet, J. \& P. Vasseur, 1971. Eponges des récifs coralliens de Tuléar (Madagascar). Téthys, (Suppl. 1): 51-126, pls. I-IV.

Vacelet, J., P. Vasseur \& C. Lévi, 1976. Spongiaires de la pente externe des récifs coralliens de Tuléar (sud-ouest de Madagascar). Mém. Mus. natn. Hist. nat., (A, Zool.) 99: 1-116, pls. I-X.

Watrous, L.E. \& Q.D. Wheeler, 1981. The out-group comparison method of character analysis. Syst. Zool., 30: 1-11.

Wiedenmayer, F., 1977. Shallow-water sponges of the western Bahamas (Experientia Supplementum, 28): 1-287 (Birkhaüser Verlag, Basel \& Stuttgart).

Wilson, H.V., 1925. Siliceous and horny sponges collected by the U.S. Fisheries steamer "Albatross" during the Philippine Expedition, 1907-10. Bull. U.S. natn. Mus., $100(2,4)$ : i-vii, 273-532, pls. 37-52.

Final draft received: 19 March 1993 